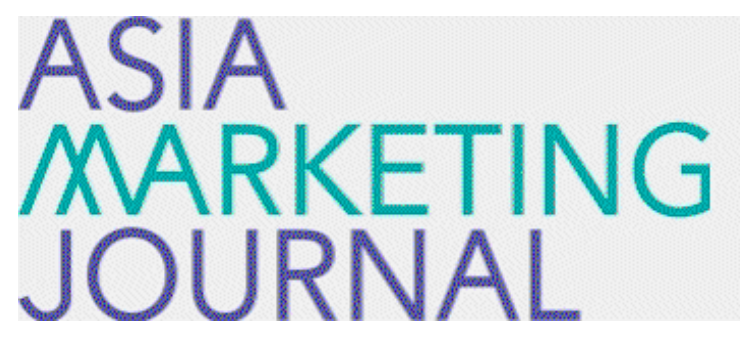

ASIA MARKETING JOURNAL

Volume 5 | Issue 4

Article 7

$12-25-2003$

\title{
유한킴벌리의 공익연계마케팅
}

성호 이

의록 홯

길상 안

Follow this and additional works at: https://amj.kma.re.kr/journal

Part of the Marketing Commons

\section{Recommended Citation}

이, 성호; 활, 의 록; and 안, 길상 (2003) "유한킴벌리의 공익연계마케팅, " Asia Marketing Journal: Vol. 5 : Iss. 4 , Article 7.

Available at: https://doi.org/10.53728/2765-6500.1118

This Article is brought to you for free and open access by Asia Marketing Journal. It has been accepted for inclusion in Asia Marketing Journal by an authorized editor of Asia Marketing Journal. 


\title{
유한킴벌리의 공익연계마케탕*
}

\section{Cause-Related Marketing of Yuhan-Kimberly}

\author{
이성호(서울시립대학교 경영학부 부교수) \\ shlee@uos.ac.kr \\ 황의록(아주대학교 경영학부 교수) \\ hwangremadang. ajou.ac.kr \\ 안길상(충북대확교 경영학부 교수) \\ ahn2334@trut .chungbuk.ac.kr
}

\begin{abstract}
기업의 사회적 책임 인식이 미약한 편인 우리나라의 경우 사희공헌활동도 대부분 구호차 원에서 전개되어 왔다고 하여도 과언이 아니며, 대부분의 활동도 일부 대기업을 중심으로 이루어져 왔다. 한편 최근 몇몇 기업들이 공익과 기업의 성공이라는 두 목적을 성취하려는 공익연계마케팅(cause-related marketing)에 대하여 증진된 관심을 보이고 있는 가운데 우 리가 참고할 만한 사례로는 어떠한 것이 있을까 ? 우리나라 공익연계마케팅의 시작이라고 볼 수 있는 사례는 유한킴벌리가 1984년부터 시작하여 지금까지 진행하여 온 '우리강산 푸 르게 푸르게' 캠페인이다. 물론 많은 어려움과 위험을 내포하고 있겠지만, 우리나라의 공익 연계마케팅활동이 더욱 확산·활성화되기를 회망하는 것이 본 사례연구의 거시적 취지이다. 구체적으로 본 사례는 유한킴벌리의 공익연계마케팅활동의 내용을 상세히 살펴본 후 관리적 차원에서 그 내용을 분석하였다. 또한 공익연계마케팅활동의 바람직한 방향과 시사점, 그리 고 더 생각해 보아야 할 과제들에 관하여 논의하였다.
\end{abstract}

\footnotetext{
*사례접수 : 03.11 게재확정 : 03. 12

본 사례개발을 위해 적극적인 도움을 주신 주유한킴벌리의 이은욱 전무님과 손숭우 팀장님께 진심으

로 감사 드립니다.
} 


\section{1. 서 론}

기업 박애주의(corporate philanthropy) 관련 문헌은 자발적인 공헌활동(through-thefirm giving; voluntarily doing good), 의무화 되어가는 기업의 사회적 책임(corporate statesmanship; mandated corporate social responsibility), 그리고 이익동기에 의해 유발 된 공헌(profit-motivated giving; doing better by doing good)으로 미국기업의 박애주의 흐름을 설명하고 있다(Varadarajan \& Menon, 1988).

의무화 되어가는 기업의 사희적 책임이 강조되던 시절 미국의 킴벌리사 또한 기업시민으 로서의 사회공헌활동을 다양하게 펼치고 있었다. 한편 유한양행의 사희환원 철학과 미국 합 작사의 기업의 사희적 책임에 영향을 받은 유한킴벌리는 기업시민으로서의 사희공헌을 회사 의 경영방침에 포함시켰다. 그리고 이 방침을 구체적으로 실현하는 프로그램으로 1984년부 터 '우리강산 푸르게 푸르게' 라는 환경보전 캠페인을 시작하였다. 처음에는 숲의 공익적 가치를 중요하게 인식하고 이 가치를 증진시키기 위한 실천 유도 제안을 하자는 것이 캠페 인의 주요 취지이었다.

중요한 점온 이 캠페인을 지난 20 년간 지속적으로 일관성을 가지고 추진하면서 유한킴벌 리는 구체적인 공읙 프로그램들을 창출하여 실행하는 능력올 갖추게 되었다는 점이다. 나아 가 이 과정 속에서 이러한 공익 프로그램들이 결국 기업의 가치와 연계된다는 확신과 자신 감올 얻게 된 점 또한 중요하다. 즉 이러한 내부실행체제의 자신감과 더불어 획득된 확습역 량은 유한킴벌리의 차별화된 경쟁우위의 원천으로 평가된다.

한편 Varadarajan과 Menon이 내린 정의에 따르면, 공익연계마케팅(cause-related marketing, 이하 (RM)이란 "기업이 톡정공익주제를 설정하고, 그 주제를 접한 고객이 기업 과 개인의 목적을 만족시키는 교환을 할 때, 그 교환에 전제를 두고 기업이 자신의 수입에 서 미리 약정한 일정금액을 띠어 그 공익에 기여한다는 제안의 특징을 가진 마케팅활동을 수립·실행하는 과정(the process of formulating and implementing marketing activities that are characterized by an offer from the firm to contribute a specified amount to a designated cause when customers engage in revenue-providing exchanges that satisfy organizational and individual objectives (Varadarajan \& Menon, 1988, p.60))" 이다. 이렇듯, 공익연계마케팅의 정의는 이익동기에 의해 유발된 공헌이 강조된 시기에 형성되었 다. 이러한 정의에 따르면 유한킴벌리의 '우리강산 푸르게 푸르게' 캠페인은 공익연계마 케팅에 해당되기 어려우며, 오히려 기업박애주의, 기업후원활동(corporate sponsorship), 또는 공중관계활동(public relations)의 통합활동으로 정의될 수 있을 것이다.

비록 고객의 교환에 전제를 둔 기여행위가 공익연계마케팅의 필수적 구성요소라는 주장에 도 불구하고, 기업 박애주의의 목적과 마케텅 목적과의 합치성 관점이라는 광의적 의미에서 유한킴벌리의 공익활동은 공익연계마케팅으로 정의될 수 있다는 것이 본 사례 연구진의 입 장이다. 즉 교환에 전제를 둔 기여가 아니더라도 공익 프로그램들이 기업의 가치와 연계된 다는 관점에서 공익연계마케팅의 정의가 이루어지는 것이 바람직하다는 것이 본 연구의 전 제이며, 이러한 전제는 최근 연구결과에 의하여 지지되고 있다(윤각·서상희, 2003).

특히 CRM에 관한 최근 연구는 보다 적극적으로 CRN의 성격과 활동범위를 확장시키고 있다. 예를 들어 Baron과 Miyazaki와 Taylor (2000)는 CRM은 기업이 사희적 공익(cause)을 후원함 으로써 제품 판매 둥의 마케팅 목표 달성을 촉진시키기 위한 전략이며 경쟁기업의 브랜드와 
차별화할 수 있는 중요한 도구라고 했으며, 조형오(2000)는 CRM이 기업의 사희적 목표와 경 제적 목표를 동시에 추구할 수 있게 해주는 마케팅 기법이라고 주장하고 있다.

물론 이러한 기업 사희공헌활동의 궁극적인 동기가 상업적이라는 소비자의 부정적인 인식 으로 인하여 공익연계마케팅의 효과가 없다는 일부의 견해도 있다(Smith \& Stodghill, 1994; Webb \& Mohr, 1988). 그러나 공익연계마케팅의 효과에 관한 더 일반적인 견해는 CRM 활동이 소비자들에게 호의적인 태도를 갖게 하고(Brown \& Dacin, 1997; Ross \& Patterson, 1991), 구매의도에 긍정적인 영향을 줄 수 있다는 것이다(Kroll, 1996; Murphy, 1997; Ross \& Patterson, 1991; Sen \& Morwitz, 1996).

다음에서는 유한킴벌리에 대하여 소개한 후, 유한킴벌리의 주요 사회공헌활동 내용들을 상세히 살펴볼 것이다. 그런 후, 관리적 차원에서 이 활동들을 평가한 후, 공익연계마케팅 활동의 바람직한 방향과 시사점, 그리고 더 생각해보아야 할 과제들을 논의하였다.

\section{2. 유한킴벌리에 대한 소개}

\section{1 연혁과 사업실적}

1970 년 3 월 30 일 설립된 유한킴벌리는 70 년대에 군포에 제 1 공장을 준공하였으며, 코텍스 ${ }^{\circledR}$ 생리대(71년), 크리넥스 훼이셜 티슈(71년)와 뽀삐화장지(74년)를 개발-출시하였으며, 1977년에는 업계 최초로 초지기계 플랜트를 콜롬비아에 수출하였다.

80 년대에는 김천에 제2공장, 그 외 부직포 공장을 준공하였으며, 국내 최초의 일자형 기 저거 크린베베 ${ }^{\circledR}(80$ 년 $)$, 국내 최초의 팬티형 기저귀 하기스 ${ }^{\circledR}(83$ 년), 그리고 국내 최초의 팬 티라이너 코텍스 ${ }^{\circledR}$ 후리덤(85년)을 개발·출시하였으며, 1984년부터는 '우리 강산 푸르게 푸 르게' 캠페인을 시작하였다. 제품과 관련된 그 이후의 사업내용은 <표 1>에 상세히 설명되 어 있으며, 관리 시스템과 관련된 개선으로는 2000년 8월 물류부문에 도입한 차량위치 자동 추적 시스템(automatic vehicles location System, AVLS)에 의한 물류개선과 2001년 3월 도 입한 사원에 대한 전문가 상담지원 프로그램(employee assistance program)을 들 수 있다.

즉 제품군 구성과 제품 현황(표 1 참조)을 볼 때 유한킴벌리는 각 제품군을 개척한 선발 주자로서 사업을 전개하여 옴에 따라 각 제품군에서 선점우위(pioneering advantage)를 누 리고 있다. 구체적으로 90 년 대까지는 기저귀 제품, 생리대 제품, 화장지와 미용티슈 시장을 적극 개척하였으며, 90 년대 이후에는 가정용품시장의 종이타올, 물티슈와 성인용품시장을 개발하고 있다. 이외 산업용품과 병원용품으로의 확장과 DPT 사업으로의 진출은 계속적인 성장을 목표로 하고 있다.

그 결과, 유한킴벌리는 매출과 순이익으로 볼 때 놀라울 정도로 지속적인 성장을 하고 있 다(그림 1 참조). 유한킴벌리에 따르면, 1970년 설립 이래 고객의 사랑을 받기 위한 심충적 인 고객 조사활동의 전개, 기술 및 생산 부문으로의 아낌없는 재투자와 이에 의한 꾾임없는 제품 혁신, 건전한 재무구조의 유지 등을 바탕으로 비약적인 발전을 이룩하고 있다고 한다. 본 사례연구의 주 관심사인 유한킴벌리의 공익연계마케팅활동은 과연 유한킴벌리의 성장에 어떠한 역할을 했을 지를 염두에 두면서 구체적인 사례내용을 살펴보기로 하자. 
<표 1> 유한킴벌리의 제품군 구성과 제품현황"

\begin{tabular}{|c|c|c|c|c|}
\hline $\begin{array}{l}\text { 제품현황 } \\
\text { 제품군 구성 }\end{array}$ & 70년대 & 80년대 & 90년대 & $\begin{array}{l}2000 \text { 년대 및 } \\
2003 \text { 년 현항 }\end{array}$ \\
\hline \multirow[t]{6}{*}{ 유아용품 } & \multicolumn{4}{|l|}{ 팬티형 기저귀 } \\
\hline & - & $\begin{array}{l}\text { 하기 스 (83년) } \\
\text { 개발, 출시 }\end{array}$ & $\begin{array}{l}\text { 하기스 베이비스텁 } \\
\text { (92년), 하기스 울트 } \\
\text { 라슐립 (94년), 하기 } \\
\text { 스 프리미엄 (97년) } \\
\text { 개발, 출시 }\end{array}$ & $\begin{array}{l}\text { 하기스 골드, 하기스보 } \\
\text { 송보송 }\end{array}$ \\
\hline & \multicolumn{4}{|l|}{ 일자형 기저거 } \\
\hline & - & $\begin{array}{l}\text { 크린 베베 } \quad(80 \\
\text { 년) 개발, 출시 }\end{array}$ & - & 하기스 크린 베메 \\
\hline & \multicolumn{4}{|l|}{ 야뇨중 맨티 } \\
\hline & - & - & - & 굿나이트 \\
\hline \multirow[t]{4}{*}{ 여성용품 } & \multicolumn{4}{|l|}{ 생리대 } \\
\hline & $\begin{array}{l}\text { 코텩스 (71년) } \\
\text { 개발, 츨시 }\end{array}$ & - & $\begin{array}{l}\text { 코텩스 화이트 } \\
\text { (95년), 코텩스 } \\
\text { 줗은 느밈(99년) } \\
\text { 개발, 훌시 }\end{array}$ & 화이트 , 줗은 느낍 \\
\hline & \multicolumn{4}{|l|}{ 팬티라이너 } \\
\hline & - & $\begin{array}{l}\text { 코택스 후리덥 } \\
\text { (85년) 개발, } \\
\text { 출시 }\end{array}$ & - & 애니데이 ${ }^{-}$티니 \\
\hline \multirow[t]{8}{*}{ 가정용품 } & \multicolumn{4}{|l|}{ 화장지 } \\
\hline & $\begin{array}{l}\text { 뽀때 (74년) } \\
\text { 개발, 출시 }\end{array}$ & - & $\begin{array}{l}\text { 크리넥스 바스붐 티 } \\
\text { 슈(91년) 개발, 출시 }\end{array}$ & $\begin{array}{l}\text { 크리넥스 바스품 티슈 } \\
\text { 크리낵스 빅롤 } \\
\text { 뽀피 풀러스 } \\
\text { 비바 빅롤 }\end{array}$ \\
\hline & \multicolumn{4}{|l|}{ 미용티슈 } \\
\hline & $\begin{array}{l}\text { 크리넥스 에이셜 } \\
\text { 티슈(71년) 개발, } \\
\text { 출시 }\end{array}$ & - & $\begin{array}{l}\text { 크리낵스 울트라 해 } \\
\text { 이셜 티슈(94년) 개 } \\
\text { 발, 출시 }\end{array}$ & $\begin{array}{l}\text { 크리녁스 알로에 플러스 } \\
\text { (울트라 소프트, 미용, } \\
\text { 베이비 소프트) 티슈 } \\
\text { 스카터, 헬로키티 미용 } \\
\text { 티슈 }\end{array}$ \\
\hline & \multicolumn{4}{|l|}{ 중이타을 } \\
\hline & - & - & - & $\begin{array}{l}\text { 크리넥스 프리미엄 (플 } \\
\text { 러스, 뽑아쓰는) 키친 타 } \\
\text { 을, 비바 흠타을 }\end{array}$ \\
\hline & \multicolumn{4}{|l|}{ 납킨 } \\
\hline & - & - & - & $\begin{array}{l}\text { 크리넥스 흠 (태이불, } \\
\text { 위생) 녑킨 }\end{array}$ \\
\hline \multirow[t]{2}{*}{ 물티슈 } & \multicolumn{4}{|l|}{ 아기 믈티슈 } \\
\hline & - & $\begin{array}{l}\text { 하기스 (83년) } \\
\text { 개발, 출시 }\end{array}$ & $\begin{array}{l}\text { 하기스 베이비스텹 } \\
\text { (92년), 하기스 올트 } \\
\text { 라슬립 (94년), 하기 } \\
\text { 으 프리미엄 (97년) } \\
\text { 개발, 츨시 }\end{array}$ & $\begin{array}{l}\text { 하기스 골드, 하기스 보 } \\
\text { 송보송 }\end{array}$ \\
\hline
\end{tabular}




\begin{tabular}{|c|c|c|c|c|}
\hline & - & \begin{tabular}{|l|} 
크린베베 $(80$ \\
년) 개발, 출시
\end{tabular} & - & 하기스 크린베배 \\
\hline & \multicolumn{4}{|c|}{ 핸드 앤 훼이셜 풀티슈 } \\
\hline & - & - & - & 굿나이트 \\
\hline \multirow[t]{8}{*}{ 성인용품 } & \multicolumn{4}{|c|}{ 안심위생 퓬티 } \\
\hline & - & - & $\begin{array}{l}\text { 디팬드 성인용 안심 } \\
\text { 위생 탠티 ( } 93 \text { 년) 개발, } \\
\text { 출시 }\end{array}$ & $\begin{array}{l}\text { 다몐드 프리미엄 골드 } \\
\text { (프리미엄, 일반형) }\end{array}$ \\
\hline & \multicolumn{4}{|c|}{ 소변용 패드 } \\
\hline & - & - & - & 디 펜드 소변용 패드 \\
\hline & \multicolumn{4}{|c|}{ 위생 매트 } \\
\hline & - & - & - & 디팬드 위생갈개 매트 \\
\hline & \multicolumn{4}{|c|}{ 요실금 댄티 } \\
\hline & - & - & - & 디팬드 ${ }^{\circledR}$ 요실금 퐨티 \\
\hline 산업용품 & \multicolumn{4}{|c|}{$\begin{array}{l}2003 \text { 년 현황 : } \\
\text { 와이퍼, 작업복, 액세서리, 마스크, 유홉착재, 핸드타올, 화장지, 방향제, 세정제, 좌변 } \\
\text { 기 커버, 물비누, 냅킨, 전용 용기 (80년대부터 꾸준히 개발) }\end{array}$} \\
\hline 병원용품 & \multicolumn{4}{|c|}{$\begin{array}{l}\text { 2003년 현황 : } \\
\text { 병원용 수술포, 수술용 마스크, 소독포, 의료용 액세서리 (80년대부터 꾸준히 개발) }\end{array}$} \\
\hline $\mathrm{DPT}$ 사업 & \multicolumn{4}{|c|}{$\begin{array}{l}\text { 2003년 현황 : } \\
\text { 디지털날염 프린터, 디지털날염 소프트웨어, 소모품, 기타장비 (2001년부터 출범) }\end{array}$} \\
\hline
\end{tabular}

* 자료원 : 유한킴벌리 대외협력실 내부보고서(2003. 6.)

\section{2 경영철학}

유한킴벌리는 '소비자가 선호하는 유익한 제품과 서비스를 공급하여 위생문화 발전을 선 도하고 건강과 복지향상에 기여한다' 는 것을 기업의 기본사명으로 삼고 있다. 즉 사업범 위(scope of business domains)를 정의함에 있어 위생문화, 건강과 복지향상이라는 소비자 혜택을 중시함으로써 제품 및 사업 선정의 융통성(flexibility)과 성장을 강조하고 있다 (Kotler, 1997).

이러한 사명을 완수하기 위하여 필요한 경영원칙으로 첫째, 인간존중 경영, 둘째, 고객만 족 경영, 쎗째, 사회공헌 경영, 넷째, 가치창조 경영, 그리고 다섯째, 혁신주도 경영이 설 정되어 있다. 먼저 인간존중의 경영원칙을 살펴보면, 유한킴벌리는 사원의 안전을 제 1 순위 로 하는 생명존중 정신의 실현, 사원 상호간의 신뢰형성, 회사와 사원간의 원활한 커뮤니케 이션을 통한 열린 경영의 실천, 희사 성공의 주역인 인재의 양성, 성공에 기여한 사람에 대 한 공정한 보상 둥을 통해 인간존중을 실현하고 있다고 한다.

둘째, 항상 고객의 입장에서 생각하는 자세를 바탕으로 고객에게 최고의 가치를 주는 고 품질의 제품올 만들어 제공함으로써 희사와 고객이 함께 성장하는 길을 만들고자 노력하고 있다고 한다. 셋째, 선도적 환경보전 활동의 전개, 윤리적 경영의 실천, 공정한 거래, 성실 한 납세 실천을 통해 사회에 공헌하는 기업이 되고자 최선을 다하고 있다고 한다.

넷째, 미래를 위한 성장을 추구하며, 생산성을 향상시키며, 좋은 기업 평판을 얻고자 노 력하는 과정에서 유한킴벌리는 가치를 창조하고 있다고 한다. 마지막으로 모든 부문에서 앞 서 나가려는 도전정신의 함양과 이를 뒷받침해 주는 학습조직의 활성화, 아울러 업무의 유 연성 확보와 변화를 주도하는 자세의 학립을 통해 혁신을 주도하고 있다고 한다. 

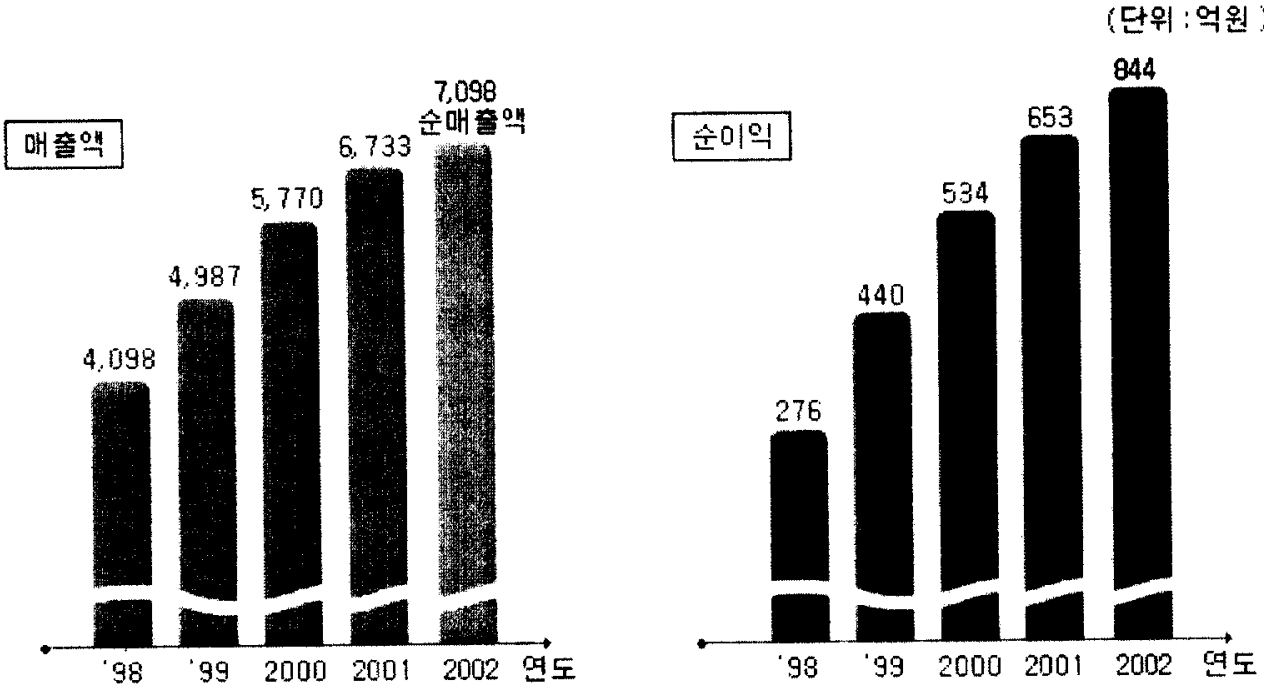

* 자료원 : 유한킴벌리 경영사례 발표자료(2003. 8.)

이러한 유한킴벌리의 경영원칙 중 가장 차별화된 원칙은 사회공헌 경영의 원칙이라 할 수 있다. 공익과 연계한 사희공헌활동의 전개와 학습은 또 다른 한편으로 환경방침의 설정과 이에 의한 환경경영과 밀접한 관계를 가치며 유한킴벌리의 기업가치를 지탱해주고 있다고 평가할 수 있다.

구체적으로 유한킴벌리는 아기 기저퀴, 여성 생리대, 화장지, 부직포 등 제품의 설계, 제 조, 운송, 판매 및 서비스 활동으로부터 수반되는 모든 환경영향을 최소화하기 위하여 환경 부하의 최소화, 지속적인 환경개선, 환경보호 운동에 선도적 역할, 효율적인 환경관리, 조 직원의 환경관리능력 배양, 환경방침 공개라는 환경방침율 설정·운영하고 있으며 그 결과를 2002년부터 공개하고 있다 (www.yuhan-kimberly.co.kr 환경경영보고서 참조). 이러한 환경경 영 방침의 수립과 실행의 원천은 1984년부터 시작한 유한킴벌리의 '우리강산 푸르게 푸르 게' 라는 환경보전 캠페인에 있었다. 지금부터 이 캠페인의 내용과 진화과정을 상세히 살펴 보기로 하겠다.

\section{3. ‘우리강산 푸르게 푸르게’ 캠페인}

유한킴벌리는 환경보전을 위해 1984년부터 나무를 심고 가꾸는 ‘우리강산 푸르게 푸르 게' 캠페인을 전개해 오고 있다. 이러한 일은 우리나라는 산지가 국토의 $65 \%$ 나 되면서도 임목축적이 자연선진국의 $1 / 3$ 에 불과 하고, 연간 강우량이 1,300 억 톤이나 되면서도 물이 부족한 나라이기 때문에 꼭 필요한 일임을 인식하고 환경보전 활동을 실천하기 위하여 시작 한 일이었다. 아마 처음에는 숟을 가꾸어야 하는 이유를 보다 많온 사람들에게 알리면서 환 경보전 활동을 실천해 나가면 유한킴벌리 사업에 대한 비난 요소률 제거할 수 있으리라는 
기대를 가지고 이 캠페인을 시작하였을 것이다. 그러나 재미있고 중요한 점은 지속성과 일 관성을 가지고 이 캠패인을 전개하면서 유한킴벌리는 여러 공익단체와 공동으로 프로그램을 창출하고 운영하는 경험과 능력올 보유하게 되었다는 점이다. 즉, 유한킴벌리는 환경 선진 국이 되지 않고는 진정한 선진국이 될 수 없다는 인식을 확고히 갖게 되었고 이러한 인식 하에 숲의 환경적, 문화적, 경제적 가치를 높이기 위한 노력을 전개하여 오고 있다. 그러면 현재의 시점에서 '우리강산 푸르게 푸르게' 캠페인의 구성내용을 살펴보도록 하겠다.

\section{1 시범림 조성사업}

\subsection{1 사업내용}

시범림 조성사업은 1984년부터 현재까지 20년쩨 지속되어 오는 사업으로 숲에 나무를 심 고 가꾸는 일을 위하여 기금을 조성·사용하여 오고 있다. 1984년 8월 14일 1차로 $50,000,000$ 원의 기금올 조성한 이래 2003 년 11 월 30 일 현재 총 69 차에 걸쳐 총 47 억 3 천만 원의 기금을 조성·사용하였다.

체계적으로 나무심기, 숲 가꾸기와 숲길 만들기 사업을 펼쳐오고 있는데, 나무심기 사업 은 85년부터 2002년까지 전국에 걸쳐 463만평에 500만 그루의 나무를 심은 실적을 보여주고 있으며, 시간이 흐름에 따라 지역 환경을 고려한 자생적인 수종의 나무심기로 그 사업내용 이 다듬어졌다. 나무심기에서 더 나아가 나무가 잘 자랄 수 있는 환경을 고려하여 천연림보 육, 솎아내기, 비료주기, 병충해 방제 둥으로 이루어진 혼효림 조성을 위한 숲 가꾸기 사업 을 1,979 만평, 1,500 만 그루를 대상으로 실행하여 왔다. 이와 더불어 총 $59.8 \mathrm{~km}$ 에 이르는 환경친화적 숲길을 신설 또는 보수하여 왔다. 시범림 조성사업의 전체 실적으로 유한킴벌리 는 85 년부터 2003년 현재까지 국내외에 걸쳐 3 천 5 백만 여 그루의 나무를 심고 가꾸어 왔다. 이렇게 다양한 사업내용의 실행이 가능했던 것은 무엇보다 전문가로 구성된 '우리강산 푸 르게 푸르게” 의 운영위원회를 산립조합중앙회에 설치하여 시범림 조성계힉, 기금운영 및 실행을 해 왔기 때문이다. 또 다른 이유는 다양한 유관조직과의 적극적인 협력활동에서 찾 아볼 수 있다.

\section{1 .2 숲 운동의 발전과정 ${ }^{1}$}

우리나라의 숲 운동은 1973년 정부가 치산 녹화 사업을 전개하며 시작되었다. 산립청과 산림조합중앙희가 주도적으로 나서 나무심기운동과 산 보호 운동을 전개하였다. 이러한 상 황에서 유한킴벌리는 1984년부터 '우리강산 푸르게 푸르게(Keep Korea Green)' 캠페인을 시작하면서 산림자원 육성기금을 조성하였고, 신혼부부를 대상으로 한 나무심기활동, 청소 년을 대상으로 한 그린캠프 운영, 연구지원 및 홍보활동 둥을 다양하게 펼쳐나갔다 ${ }^{2}$.

1997년 불어 닥친 IMF 외환·경제 위기는 숲 운동을 새로운 방향으로 전환시키는 계기가 되었다. 유한킴벌리는 환경운동연합, 경실련, 참여연대, 시민의 신문 등 시민단체와 협업하 여 외환위기로 인해 발생한 실직자를 환경보전 활동에 참여 시킬 것을 정부 둥 각계 지도층 에 제안하는 노력을 경주하였다. 이러한 프로그램은 그 자체로도 의미가 있었지만 더욱 중 요한 점은 이 일로 인해 숲 운동은 정부주도나 기업주도가 아닌 그야말로 다 영역간 협력운

\footnotetext{
1 숲 운동의 발전과정은 그림 2에 도식화되어 요약되어 있음.

2 논의의 전개 상 이러한 활동내용은 3.3 환경교육과 3.4 연구지원 및 환경광고 부분에 설명되었음.
} 
동으로 진화하게 된 점이다. 97 년과 98 년도의 주요 협력혈동으로는 숲 가꾸기(숲 체헙, 시 민의 숲 - 마을 숲 가꾸기, 아름다운 숲 운동, 학교 숲 가꾸기 둥), 야생동물보호, 환경교 육자료 보급, 숲 보호지역 발굴 둥이 있으며, 그 이후로는 북한 산립복구 할동과 함꼐 동북 아 사막화 방지 둥 국제협력활동이 적극 진행되어 오고 있다.

즉, 숲 보호라는 공익에 대한 유한킴벌리의 지속적·일관된 관심은 처음에는 상상도 하지 못한 다양한 공익프로그램의 창출과 참여로 연결되었던 것이다. 보다 많은 사람들이 숲을 사랑하고 숲 보호활동에 참여할 수 있도록 고민을 거듭한 결과, 우리 사회에 숲에 관심을 가지고 숲 보호 활동에 참여하는 학자 둥의 전문가 집단과 환경보호 시민단체가 많음을 인 식하고 이들과 협력하게 되었다. 그 결과, 유한킴벌리 단독으로 이 캠페인을 전개하는 시나 리오 하에서 얻을 수 있는 결과와는 비교할 수 없을 정도의 다양한 프로그램 참여와 실행성 과를 보여주고 있다. 다음에서는 이러한 숲 보호단체와의 협력 프로그램을 살펴보기로 한다.

\section{2 숲 보호단체와의 협력 활동}

\section{2 .1 생명의 숲 국민운동 참여}

1998년에 창립된 숲 보호 시민단체인 '생명의 숲 국민운동' 은 숲 가꾸기 사업을 통하여 일시적이지만 실직자의 대규모 고용을 창출시켰다. 이로 인하여 산립의 환경기능이 강화되 었다고 볼 수 있다. 자원으로서의 미래 숲 가꾸기 사업의 중요성을 공유한 유한킴벌리는 시 민참여 프로그램의 실행에 적극적으로 참여하였으며, 아름다운 숲 전국대회, 생명의 숲 음 악회, 국제 워크샵, 박람회 전시관 운영 둥 교욕·훙보·문화 활동을 적극 후원하였다.

특히 유한킴벌리의 문국현 사장이 '생명의 숲 가꾸기 국민운동' 의 공동운영위원장으로서 주도적인 제안을 펼친 점과 유한킴벌리의 많은 임직원들이 펼친 자원봉사는 이 운동의 확산 에 큰 역할을 하였다.

\section{2 .2 확교 숲 만들기 지원}

우리나라 9700 여 개 학교 대부분은 그 땅(약 5,400 만평)에 흙먼지가 날리고 있으며 담장 과 희색 콘크리트 건물에 둘러싸여 있는 현황이다. 유한킴벌리는 1999년에 1 억 4 천만원, 2000 년에 2 억원, 2001 년에 2 억 5천만원의 학교 숲 기금을 조성하여 '생명의 숲 국민운동' 에 기탁함으로써, 전국 초, 중, 고등학교가 숲이 있는 학교를 만들어 갈 수 있도록 돕고 있다. 기금의 조성·기탁 외에 유한킴벌리는 '생명의 숲 국민운동' 과 산립청과 협력하여 국제 심 포지엄, 토론회, 워크샵, 선진 사례 견학, 묘목 제공, 기술 지도 및 교육 프로그램 개발 둥 을 함께 실시하였다. 또한 숲이 있는 학교 만들기 매뉴얼올 제작하여 무료로 보급하고 있음 을 볼 때 이 프로그램에 대한 유한킴벌리의 높은 관여도를 짐작할 수 있다. 2002년 중반까 지 선정된 총 65 여 개 시범학교에는 나무, 전문가의 자문활동, 교육 프로그램 둥이 지원되 고 있으며, 이러한 활동은 전국 모든 확교에 숲이 만들어질 수 있도록 하는 데에 좋은 사례 역할올 할 것이다. 이러한 학교 솦 만들기 지원사업은 '생명의 숲' , 지방자치단체와 함께 도시 숲 조성사업으로도 확장되어 가고 있는 추세이다. 
<그립 2> 숲 운동의 발전과정"

(Since 1973)

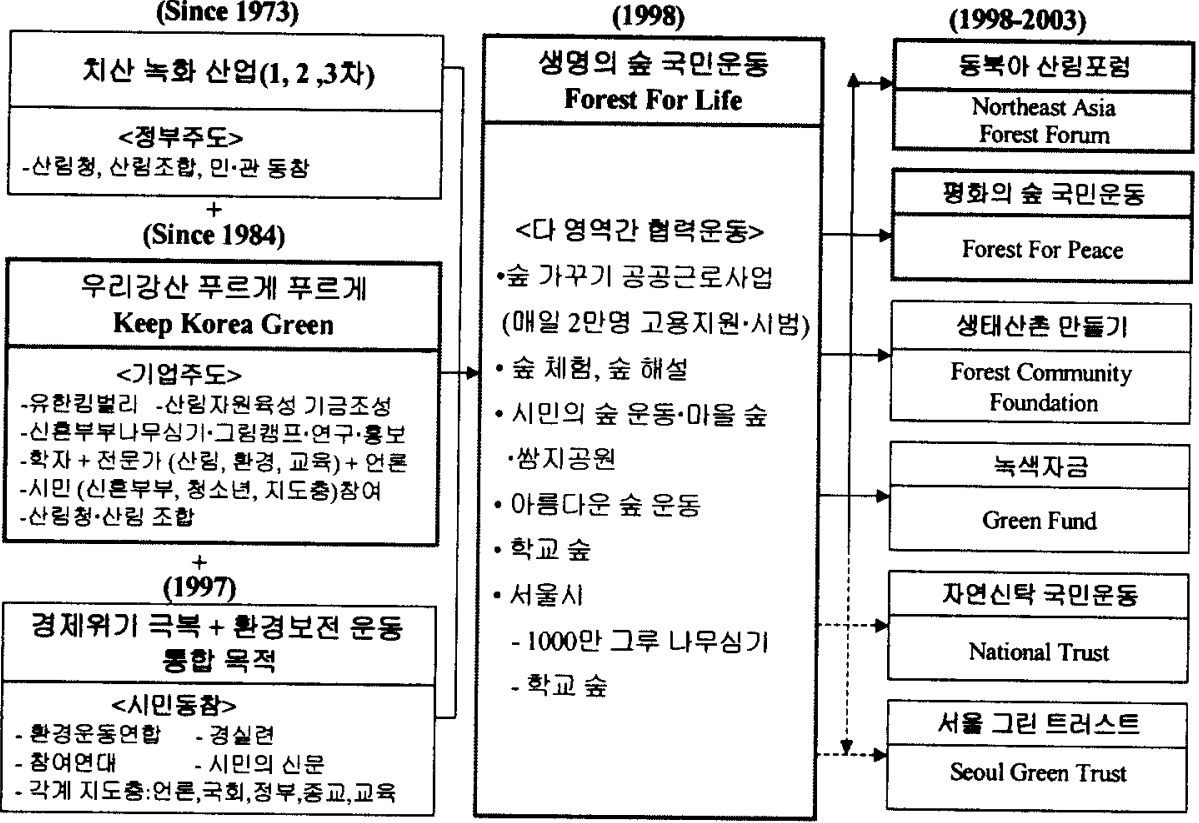

* 자료원 : 유한킴벌리 경영사례 발표자료(2003. 8.)

\subsubsection{8 년 이후의 적극적인 참여활동}

'생명의 숲 국민운동' 참여 이후 유한킴벌리는 보다 세부적인 숲 보호 목적올 가지고 활동하고 있는 여러 단체들과 협력 활동을 전개하고 있다.

1999년부터 유한킴벌리는 황폐화된 북한 숲의 복구 지원을 통하여 한반도 환경보전에 기 여하는 목표를 가지고 활동하는 시민단체인 '평화의 숲' 활동에 참여하기 시작하였다. 이 기관의 주요 활동내용은 북한 숲의 황폐화 현황을 국민에게 알리는 일, 복구를 위한 기금 모금, 산립 황폐지에 대한 물자 전달, 양묘장 조성 지원 등인데, 유한킴벌리의 참여는 묘목, 종자, 임업장비 둥 물자 지원, 현지 조사 참여, 전문가 협력 둥의 분야에서 이루어져 왔다.

또한 1999년부터 유한킴벌리는 '동북아 산림 포럼' 에 참여하기 시작하였다. 한국, 중국, 몽골 둥 동북아의 산림생태학자가 주축이 된 이 포럼은 동북아 사막화 방지를 위해 협력하 는 단체이다. 구체적으로 동북아의 사막화 방지와 산림 생태 복원을 위한 연구, 현지 조사 및 학술행사 지원, 나무심기 활동에의 참여, 출판 둥의 활동에 협력해 오고 있다.

2000년 1월부터 유한킴벌리는 '내셔널 트러스트' 운동에 참여하고 있다. 이 운동은 자 연과 문화 자산이 개발이라는 명목 하에 모습을 잃어가고 있음을 안타깝게 여겨 시민들의 기증이나 모금 등의 실질적인 참여를 통해 환경 가치를 지키려는 시민 운동이다. 이 운동의 주요 내용은 보존 가치가 있는 자연 및 문화 유산 지역을 발굴하고 알리는 활동, 해당 지역 을 보호하는 활동, 선진국의 사례조사 활동을 지원하는 내용 등으로 구성되어 있다.

또한 유한킴벌리는 뉴욕의 센트럴파크롤 모델로 하여 태동하고 있는 서울그린트러스트 운 동에 참여하고 있으며 이 운동의 확대를 위하여 노력하고 있다. 이 운동은 서울시, 시민, 단체, 기업이 재정출연 및 지원, 기부, 모금, 회비, 자원봉사활동을 통하여 서울의 녹지를 
복원·확대하기 위한 운동이다(그림 3 참조).

지금까지 98 년 이후 급속하게 전환되고 있는 숲 운동의 발전과정에 참여해 온 유한킴벌리 의 모습을 살펴보았다. 다음에서는 유한킴벌리가 특별히 중점을 두고 진행해 왔던 환경교육 활동의 내용을 알아보기로 한다.

\section{3 환경교육}

\subsection{1 청소년 환경체험교육}

미래의 주인인 청소년들이 자연환경의 소중함을 느낄 수 있어야 한다는 인식을 갖고 유한 킴벌리는 1988년부터 숲 체험 활동을 통한 미래 숲 전문가를 양성한다는 목적 하에 청소년 환경체험교육인 그린캠프를 운영하여 오고 있다.

'유엔 의제 $21^{\prime}$ 에서 생활환경 보호에 있어 주부와 청소년들의 역할을 가장 중요하게 꼽고 있는 바, 미래 환경의 주역인 여고생들을 대상으로 미래 환경에 대한 책임감을 길러주는 것 이 중요하다고 판단한 유한킴벌리는 이 프로그램의 대상을 전국 여자고등학교 학생으로 특 화하고 있다.

1988 년 이후 17 년째 이어지고 있는 그린캠프는 지금까지 2,324 명의 교육수료생을 배출하 였는데, 이 프로그램은 국내에서 손꼽히는 환경체험 캠프로 평가되고 있다. 이렇게 평가되 고 있는 이유는 산림, 환경, 경제, 과학 분야 등의 대학교수와 예술가 등 각 분야의 권위 있는 전문가들이 참여하고 있기 때문이며, 또한 유한킴벌리를 포함하여 협력기관의 구성원 들이 캐나다, 호주, 코스타리카, 케냐, 블티시 웨스트 인디스, 멕시코 등 세계 6개 지역에 서 운영하고 있는 세계적인 환경체험 교육기관의 SFS (The School for Field Studies) 교육 방식을 도입하였기 때문이기도 하다.

<그림 3> 서울그린트러스트 운동의 원리*

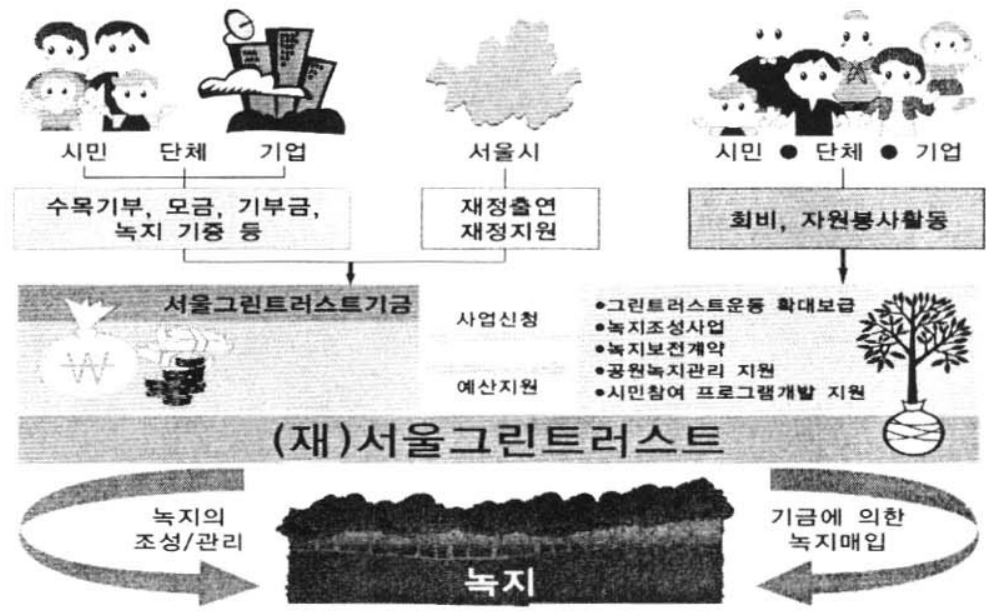

* 자료원 : 서울그린트러스트 자료집(2003. 6.) 
나무와 물, 토양, 생물들을 직접 보고, 듣고, 만지며 느끼는 필드 스터디 방식의 체험 프 로그램에 대한 참여자의 반웅과 피드백이 매우 호의적이어서, 숲의 수자원 함양, 수질 정화, 대기, 생물 다양성 등과 우리 국악과 물놀이 등으로 구성된 교육 프로그램을 지속적으로 개 선시키고 있다고 한다.

\section{3 .2 신혼부부 나무심기 체험}

이 프로그램은 1985 년부터 시작하여 20 회가 되었으며, 지금까지 1 만 3 천 여 명이 참여하 였다. 새롭게 가정을 꾸민 신혼부부에게 직접 나무를 심고 자연을 접할 기회를 제공하여 숲 의 중요성을 깨닫고 새로운 인생의 출발을 다짐하는 계기를 마련하고자 신혼부부 나무심기 를 매년 식목일 즈음에 개최하고 있다. 이 프로그램은 나무가 잘 자라지 못한 지역을 선정 하여 다시 건강한 어린묘목을 심는 행사로 올바른 나무심기 방법 교육에 이어, 전문가의 지 도 하에 부부별로 정해진 지역에 나무를 직접 심는 순서로 진행된다.

\subsection{3 환경교육에 대한 논의와 숲에 관한 정보사이트}

청소년 환경 체험교육의 대상인 여자고둥학생, 그리고 신혼부부 나무심기 체험행사의 대 상인 신혼부부는 유한킴벌리 주요 고객충과 관련성이 있으므로 이러한 캠페인이 무의식적인 (unobtrusive) 의도를 가지고 있는 것이 아닌가에 대한 일부의 의구심이 있는 것도 사실이 다. 그러나 본 사례 집필진은 실사과정을 통한 경험, 프로그램 내용의 지속성, 그리고 공익 연계마케팅의 목적을 고려하여 이러한 환경교육을 공익과 기업의 성공이라는 두 목적을 자 연스럽게 연계한 활동으로 평가하는 바이다. 유한킴벌리가 운영하는 숲에 관한 정보사이트

<그림 4> 포리스트코리아의 초기화면

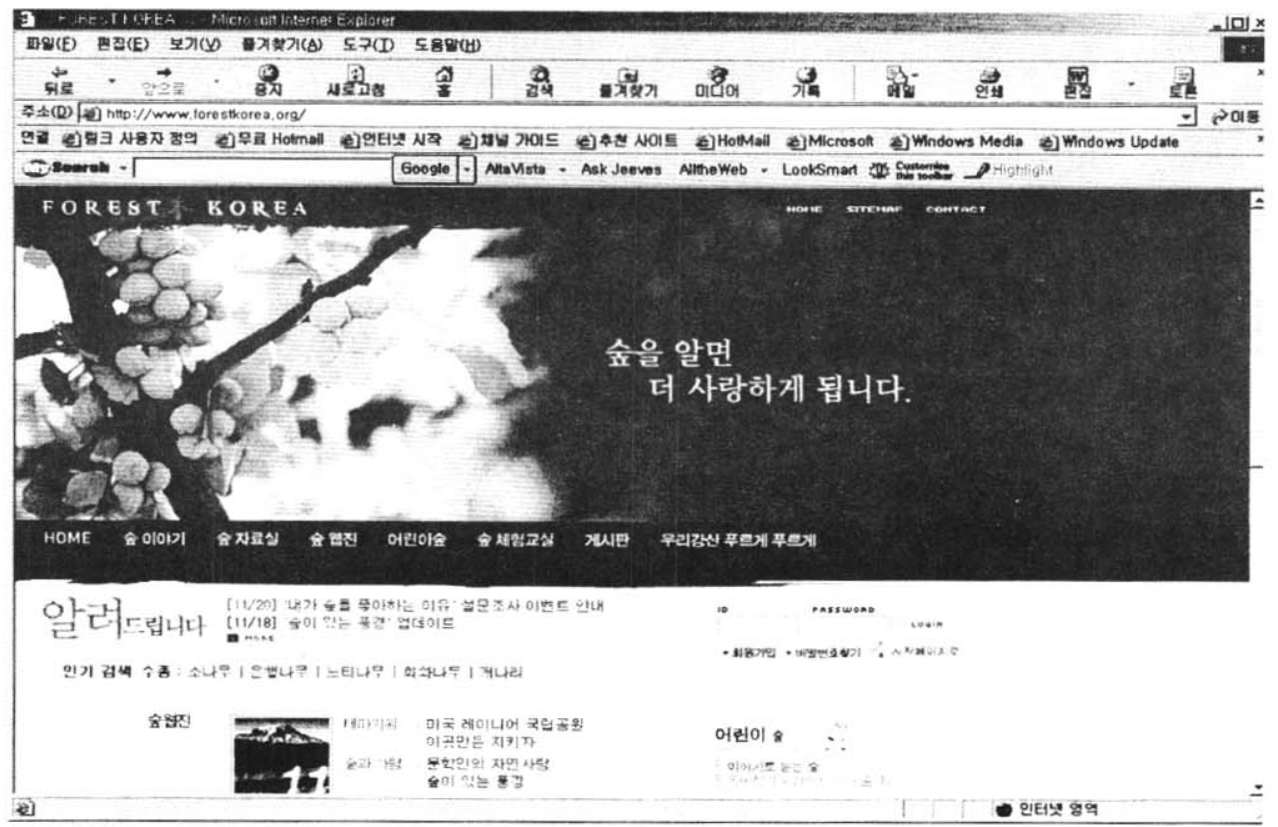


인 포리스트코리아(www.forestkorea.org)를 살펴보면 이러한 평가에 어느 정도 동의할 수 있을 것 같다.

창립 30 주년을 맞아 유한킴벌리가 기획·실행한 사회공헌 프로그램은 숲과 숲 보호에 관한 정보 포털 사이트의 구축과 운영이었다. 2000년 12월 30일 오픈한 포리스트 코리아 사이트 는 Yahoo Korea가 선정한 2001년 최고의 사이트, 2002년 정보통신부가 선정한 청소년 권장 사이트 둥 그 평가현황이 시사하듯 매우 유익하고 알짠 내용으로 구성되어 있다(그림 4 참 조). 즉 이 사이트로 인해 숲 보호라는 공익에 대한 유한킴벌리의 높은 관여도가 다시 한 번 확인된다.

\section{4 연구지원 및 환경광고}

\section{4 .1 출판 및 환경 연구·조사 지원}

숲을 제대로 알리고 숲에 대한 폭 넓은 인식을 높이고자 '우리강산 푸르게 푸르게' 캠페 인의 일환으로 유한킴벌리는 숲에 관한 책자의 출판과 보급을 1993년부터 본격적으로 시작 하였다. 현재까지 환경보호 활동의 실천, 해외사례 소개, 숲 가꾸기 둥의 내용을 중심으로 다룬 총 5 권의 서적(회망의 솦, 숲이 있는 학교, 녹색공동체를 위한 실천, 지구를 구하자, 세계의 숲으로 가다)을 출간하였으며, 이 책자들은 전국 도서관, 학교, 시민단체 둥에 무료 로 보급되었다.

출판에서 더 나아가 건강하고 지속 가능한 미래의 숲을 준비하기 위해서는 체계적인 연구 가 필수적이라고 판단한 유한킴벌리는 1997년부터 본격적으로 숲에 대한 연구·조사 활동을 지원하기 시작하였다. 산립정책, 환경교육, 수자원 보호 둥을 중심으로 그 동안 총 17 건에 걸쳐 산립·생태전문가, 환경보호단체와 학교의 연구가 지원·수행되었다. 지원된 연구결과를 관련분야의 전문가들과 공유함으로써, 숲에 대한 올바른 정책 결정에 도움이 되는 연구·조 사의 지원은 시간이 흐름에 따라 전문가의 발굴과 양성, 숲에 대한 국민들의 인식 고양, 그 리고 민간환경활동의 활성화에 도움이 될 것으로 예상된다.

\section{4 .2 환경광고}

유한킴벌리는 대중매체률 통해 숲의 소중함을 알리고, 숲 보호 활동에 시민의 동참을 이 끌어 내기 위하여 1984년부터 '우리강산 푸르게 푸르게' 캠페인에 대한 광고활동을 펼쳐 오고 있다(그림 5 참조).

'우리강산 푸르게 푸르게' 캠페인에 대해 묻는다면 아마 많은 사람들은 그림 5와 비숫 한 종류의 광고를 이야기할 정도로 이 광고캠페인은 우리에게 친숙하다. 광고 원칙 중 일관 성의 원칙을 잘 지켜 온 우리나라의 대표적인 사례로 꼽히는 광고 활동일 것이다.

본 사례연구를 통하여 우리 모두 다시 한 번 학습할 푈요가 있는 마케팅에 관한 첫 번째 시사점은 유한킴벌리가 소비자의 욕구를 정의해 나간 부분에서 찾을 수 있다. 수단 - 목표 연쇄모형(means-end chain model; Gutman, 1982)에 따르면, 소비자의 제품관련 지식을 고려 할 때 소비자의 욕구는 구체적인 제품 속성에서 추상적인 소비자 가치의 연속선 상에서 발 견·설정될 수 있다. 즉 유한킴벌리의 공익지향성은 자연스럽게 숲 보호라는 소비자 가치를 중요하게 인식하게 하였으며 이로 인해 차별적이며 지속적인 마케텅 커뮤니케이션을 가능하 게 하였으며, 그 결과 소비자의 머리 속에서 확고히 차별화된 유한킴벌리의 포지션이 형성 되었다고 볼 수 있다. 


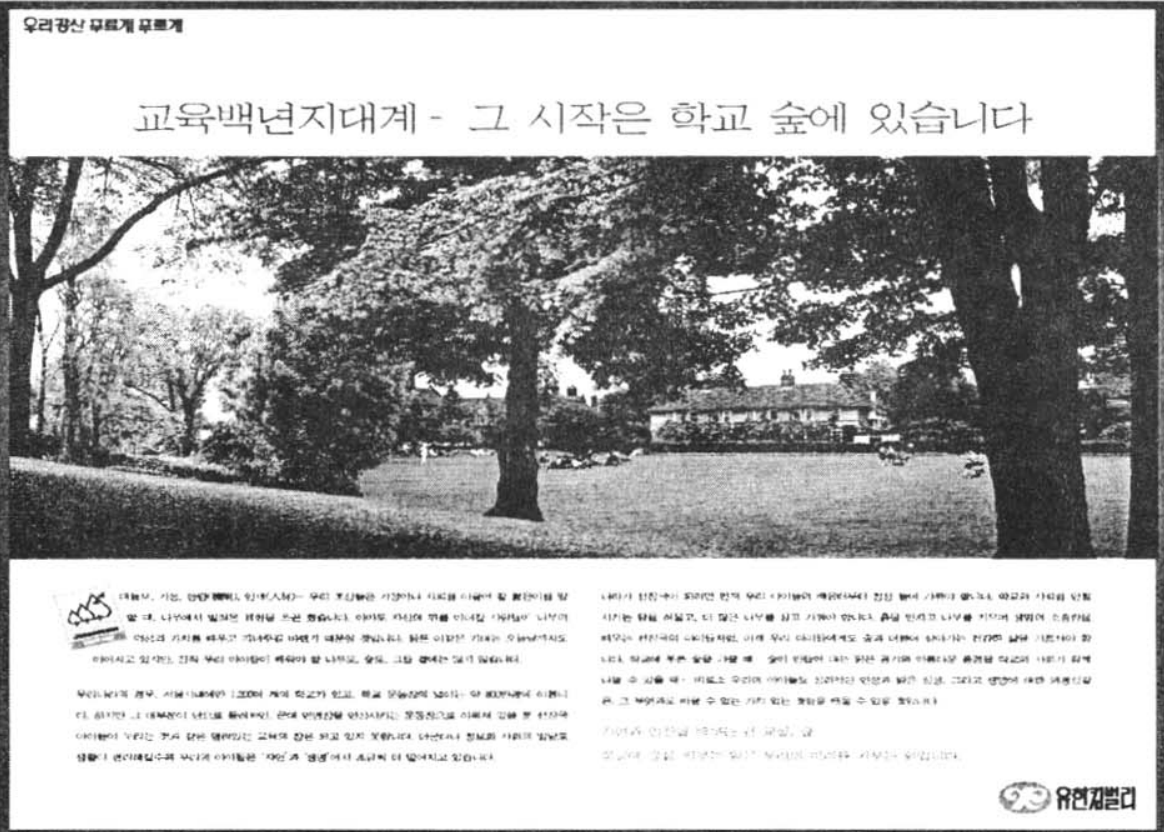

두 번째 시사점은 마케팅의 대상 차원에서 볼 때 유한킴벌리의 공익연계캠페인은 제품중 심이 아니라 기업중심의 마케팅 활동에 초점을 맞추고 있는 점에서 찾아볼 수 있다. 브랜드 자산 관련 연구(Aaker, 1991; Keller, 1993)는 브랜드 이미지의 주요 구성요소 중 하나로 추상적인 기업평가를 제시하고 있으며, Rust 등의 연구(Rust, Zeithaml, \& Lemon, 2000)는 구체적으로 기업 또는 브랜드 윤리에 대한 소비자의 지각이 중요함을 시사하고 있다. 즉 유 한킴벌리의 '우리강산 푸르게 푸르게' 캠페인은 유한킴벌리의 기업이미지를 호의적으로 만들어 나갔고, 이로 인하여 유한킴벌리의 마케팅 대상은 개별 상품이 아닌 기업, 그 자체 가 되어 갔으며, 이는 마케팅 자원의 효율적 활용으로 이어졌다고 평가할 수 있다. 또한, 이러한 평가는 기업의 사희공헌활동에 대한 소비자의 인식이 긍정적인 기업이미지를 통하여 호의적인 브랜드 태도로 연계된다는 최근의 국내연구(윤각·서상희, 2003)의 실증결과와도 일관된 것이다.

\section{5 캠페인의 요약과 기타 공헌활동}

지금까지 유한킴벌리의 ‘우리강산 푸르게 푸르게' 캠페인의 세부 내용을 살펴보았다. 처음에는 숲의 공익적 가치를 중요하게 인식하여 이 가치를 증진시키기 위한 실천 유도 제 안을 하자는 것이 캠페인의 주요 취지이었다. 하지만, 이를 지속적으로 추진하면서 유한킴 벌리는 숲이 갖는 환경적 기능의 중요성을 인식하고 활동하는 여러 시민단체 등과 협력하여 공익프로그램을 창출하고 공유하는 과정을 통하여 외부적으로는 캠페인의 공익성이 증진되 
는 효과를, 내부적으로는 솦 보호라는 공익에 대한 지식확보와 실행역량을 습득하는 효과를 얻었다.

'우리강산 푸르게 푸르게' 캠페인의 초기 공익활동을 말로 표현하면 '숲의 공익적 가 치 증진' 이겠지만, 현재는 '숲이 주는 다양한 환경적 기능(공기정화,수자원보전 및 정화, 토양보전, 야생동물 안식처 제공 둥)이 우리 삶의 질을 향상시킨다는 것을 믿고 이러한 숲 의 다양한 환경적 가치를 증진하는 것' 이란 말로 표현할 수 있을 것이다.

다음의 <표 2>는 '우리강산 푸르게 푸르게' 캠페인의 내용과 주요 협력 파트너와 메세 나 활동 둥 그 외의 공헌 활동내용올 보여주고 있다. 이제 사회공헌활동과 그 체계는 유한 킴벌리에 체화 되어 있다고 평가할 수 있다.

<표 2> 유한킴벌리의 사회공헌활동 내용과 협력 파트너*

\begin{tabular}{|c|c|c|c|}
\hline 캠페인 & 프로그램 & 내 용 & 파트너 \\
\hline \multirow{8}{*}{$\begin{array}{l}\text { 우리 } \\
\text { 강산 } \\
\text { 푸르게 } \\
\text { 푸르게 }\end{array}$} & 국유립 가꾸기 & 국유립 대상 조립, 육림, 숲길 조성 & 정부, 지자체 \\
\hline & 학교 숲 조성 & 학교 숲 & 생명의 솦, 산림청, 교욕부 \\
\hline & 도시 숲 조성 & 마을 숲, 쌈지 공원 & 생몀의 숲, 지자체 \\
\hline & 북한 숲 복원 & 양묘단지 조성 & 평화의 숲 \\
\hline & 동북아산림 생 태복구 & 중국, 몽골 우의립 조성 & 동북아산립포럼, UNDP \\
\hline & 모델 숲 보전활동 & 모델 수목원 후원 & $\begin{array}{l}\text { 내셔널트러스트, } \\
\text { 천리포수목원 }\end{array}$ \\
\hline & 솦 체헙 교육 & $\begin{array}{l}\text { 청소년 그린캠프, 신혼부부 } \\
\text { 나무심기, 대학생 국제교류 }\end{array}$ & 산림조합, 동북아산립포럼 \\
\hline & 연구조사 및 출판 & $\begin{array}{l}\text { 자연환경 현황조사, 정책 제안, } \\
\text { 환경서적 출간 둥 }\end{array}$ & 분야별 전문가 및 환경단체 \\
\hline \multirow{3}{*}{ 메세나 } & $\begin{array}{l}\text { 시민문화공간 확충 } \\
\text { 운영 }\end{array}$ & $\begin{array}{l}\text { 문학의 집 건립 후원, 문학 강좌, } \\
\text { 좌담, 전시 둥의 후원 }\end{array}$ & 문학의 집, 토지 문화관 \\
\hline & 문화 컨텐츠 개발 & 한·중·일 문화 상장 사전 둥 & 문화예술인 \\
\hline & 시민문화축제 & 세계 시민문화축제 둥 & 시민의 신문, 아름다운 재단 \\
\hline \multirow{4}{*}{ 사회발전 } & 환경보호 & 기금 조성 & 재단·단체 \\
\hline & 여성권익 보호 & 기금 조성 & 여성단체 \\
\hline & 사회 복지 & 기금 조성, 불우이웃 돕기 & 재단·단체 \\
\hline & 재난 구호 & 재해 지역 지원 & 언론·모금단체 \\
\hline
\end{tabular}

* 자료원 : 유한킴벌리 경영사례 발표자료 (2003. 8.)

\section{4. 관리적 차원 분석}

이제 '우리강산 푸르게 푸르게' 캠페인을 중심으로 유한킴벌리의 사회공헌활동을 공익 연계마케팅의 관리적 차원예서 분석해 보기로 한다. 


\section{1 전략적 차원에서의 공익연계마케팅 ${ }^{3}$}

공익연계마케팅이 전략적 차원에서 이루어지고 있는 지에 관한 여부는 주요 프로그램에 관한 의사결정에 대한 최고경영자·최고경영진의 관여도가 높은가, 프로그램에 대하여 장기 적인 몰입의 정도가 높은가, 프로그램의 개발과 실행에 많은 자원배분이 이루어지고 있는가 등으로 판단할 수 있다. 유한킴벌리의 '우리강산 푸르게 푸르게' 캠페인의 세부 내용과 진행과정을 살펴보면 이 캠페인온 각 프로그램의 단기적 마케텅 효과를 위한 전술적인 활용 보다도 전략적인 차원에 초점이 맞추어져 있음을 알 수 있다.

'우리강산 푸르게 푸르게' 캠페인을 중심으로 한 유한킴벌리 사회공헌활동의 마케팅적 목표와 취지는 무엇일까 ? 사회공헌활동이 유한킴벌리 제품들의 판매 증대와 수읙 증진이라 는 측면에 초점을 맞추었다면 이렇둣 다양하고 적극적인 공헌활동 대신 보다 제품이나 브랜 드 중심 차원에서의 마케텅에 연계되는 공익활동의 모습을 목격할 가능성이 높았올 것이다. 즉, 유한킴벌리의 사회공헌활동은 전반적으로는 기업의 위상(corporate stature) 증진에 목 표를 두고 있는 것으로 평가되며, 구체적으로는 기업의 가시성(visibility) 흭득, 기업이미 지의 중진, 기업의 사회적 책임과 공익인식 전달과 표출인 것이다. 이는 유한킴벌리의 기업 사명과 경영원칙에서도 발견되었으며, 실사과정과 대외협력실의 내부문건에서도 발견되고 있었다(그림 6 참조).

'우리강산 푸르게 푸르게' 캠페인은 시작 당시 나무심기 캠페인으로 추진되었고, 일부 소비자들은 나무와 유한킴벌리 제품과의 관련성을 고려하면서 큰 점수를 주지 않기도 하였 으며, 지금도 이러한 소비자는 있을 것이다. 그럼에도 불구하고 공익에 대한 유한킴벌리의 지속적인 관심과 실행은 공익의 확장(나무심기, 숲 보호, 숲 보호의 환경적 가치 인식과 확 산, 환경보존의 중요성과 필요한 다양한 일들), 다양한 프로그램의 창출과 실행, 다양한 파 트너와의 협력활동, 그리고 시민에 대한 적극적인 참여확장 활동으로 이어졌다. 이에 따라 유한킴벌리 공익활동의 정당성(legitimacy)은 중진되었다고 볼 수 있다.

그 외 장기적인 관점에서 유한킴벌리와 공익간의 연계성을 중진시키기 위한 노력, 전사적 차원에서 문국현 사장의 리더쉽과 많은 임직원들의 자원봉사 둥을 고려할 때 유한킴벌리의 사희공헌활동은 우리나라에서는 매우 드물고, 기업규모로 볼 때에도 매우 눈에 띠는, 전략 적 공익연계마케팅 활동으로 평가된다.

특히 실제로 기업의 사희공헌활동들이 기업이미지를 향상시키고, 제품구매를 촉진시켜 기업 의 이윤 중대에 기여하게 되었음이 해외의 여러 사례 연구들(Arnott, 1994; Carringer, 1994; Garfield, 1993; Miller, 1992)에서 보고 되어 왔음을 감안할 때, 국내에서 유한킴벌 리의 전략적 공익연계마케팅사례가 갖는 의미는 더욱 중요하다고 할 수 있다.

\section{2 공익연계마케팅에 대한 내부평가}

일반적으로 공익연계마케팅의 평가는 사회적인 목표 달성 여부 이외에 매출과 수익의 증 진도 고려하기 마련이다. 그러나 유한킴벌리의 경우는 <그립 6>에서 논의하였듯이 공익연계 마케팅활동의 결과로 기업이미지(표 3 참조)와 평판을 가장 중요하게 여기고 있다. 포스코 와 삼성을 제외하면 유한킴벌리의 기업이미지는 우리나라에서 최고의 수준에 있다.

\footnotetext{
${ }^{3}$ 이 부분의 평가 차원은 Varadarajan \& Menon (1988)에 근거를 두고 있음.
} 
<그림 6> 유한킴벌리 공익활동의 마케팅적 취지*

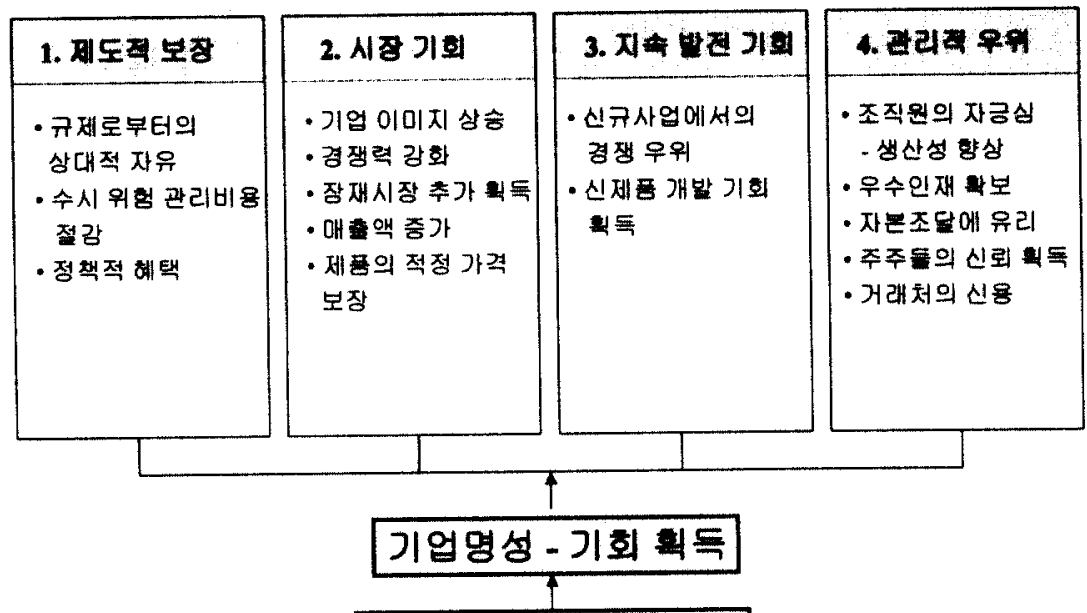

\section{유한킴벌리 공익활동}

* 자료원 : 유한킴벌리 경영사례 발표자료(2003. 8.)

<표 3> 기업이미지평가에서의 유한킴벌리 위치*

\begin{tabular}{|l|l|l|}
\hline 기업명 & 기업이미지 종합점수 & 순위 \\
\hline 포스코 & 725.2 & 1위 \\
\hline 삼성전자(컴퓨터) & 724.9 & 2 위 \\
\hline 삼성전자(통신) & 720.0 & 3 위 \\
\hline 삼성전자 & 703.9 & 4 위 \\
\hline 유한킴벌리 & 693.4 & 5 위 \\
\hline 현대자동차 & 690.3 & 6 위 \\
\hline 서울우유 & 684.6 & 7 위 \\
\hline LG화학 & 682.1 & 8 위 \\
\hline 삼성생명 & 681.0 & 9 위 \\
\hline 제일제당 & 680.1 & 10 위 \\
\hline
\end{tabular}

* 자료원 : 2002년 KMA 전략보고서

** 상품 밎 서비스품질, 사회공헌, 선호도, 신뢰도, 기술력, 성장가능성, 고객중시, 환경친화성

기업의 평빤은 각계에서 수여하는 각종 수상으로 측정하여도 그 수준을 판단할 수 있었다 (www.yuhan-kimberly.co.kr 참조). 내부적으로는 publicity 결과로 기업평판을 측정하고 있 었다(2002년 기준으로 충 408건의 publicity 건수 : CEO 관련(54건), 회사관련(153건), 대 외협력할동(47건), 제품관련(142건)). 즉 이러한 평판 평가 실적으로 볼 때 유한킴벌리 공 헌활동의 마케팅적 취지(그림 6)가 실현되고 있음을 간접적으로 알 수 있다. 나아가 유한킴 벌리는 공익연계마케팅프로그램들의 영향과 기업이미지의 역할을 다차원적으로 고려하고 있 었다(그립 7 참조). 
<그림 7> 유한킴벌리 공익활동의 관련주체(constituents)와 기업이미지의 역할*

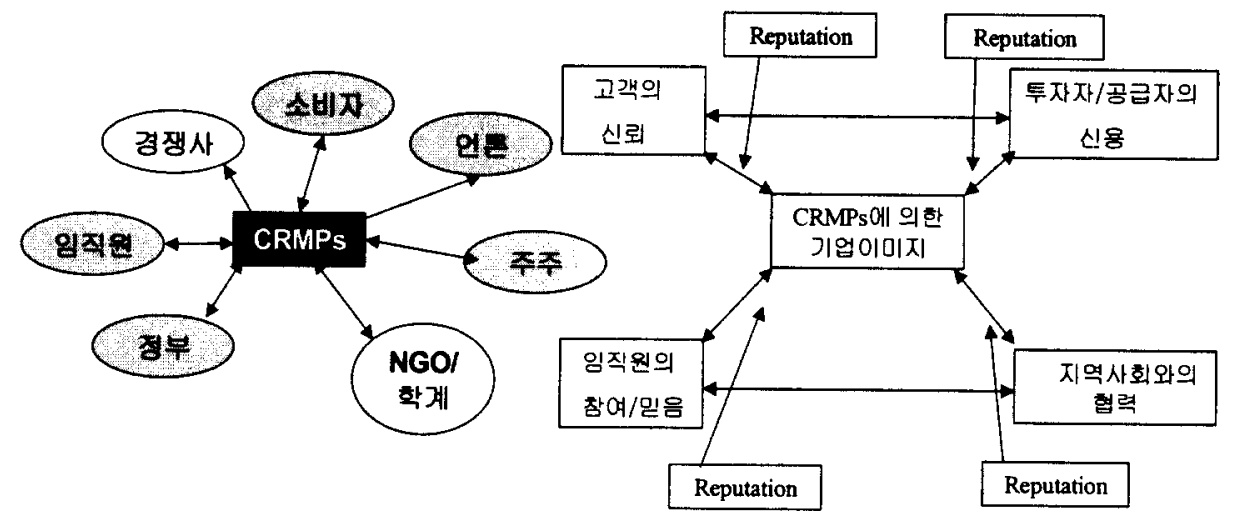

* 자료원 : 유한킴벌리 경영사례 발표자료(2003. 8.)

\section{5. 논의 및 결언}

본 사례연구는 우리나라 공익연계마케팅의 시작이자 대표적인 사례로 볼 수 있는 유한킴 벌리의 '우리강산 푸르게 푸르게' 캠페인의 1984년 시작부터 현재까지 진화되어 온 모습 을 살펴보았다.

흔히 공익연계마케팅활동에 대해서는 이러한 활동이 과연 얼마나 진실로 공익과 연계 (cause-related) 되었는가 아니면 오히려 공읙 탐익적(cause-exploitative)인 것은 아닌가 둥에 관한 논란이 제기될 수 있다. 소수의 의견이겠지만 유한킴벌리와 관련해서도 제품의 특성과 관련하여 일부 공격적인 주장들이 있는 것도 현실이다.

그러나 이러한 위험이 있다고 하더라도 공익에 대한 관심과 몰입, 이에 기반을 둔 장기적 이며 일관된 실행은 소비자에게 기업의 호의를 전달하였으며, 그 결과로 기업의 가치가 증 진될 수 있음을 유한킴벌리 사례가 보여주고 있다.

앞에서는 부분적으로 논의하였지만, 유한킴벌리의 사례로 볼 때 유추할 수 있는 공익연계 마케텅활동의 바람직한 방향을 정리해 보기로 하자. 첫째, 최고경영진의 전폭적인 관심과 지지가 어려운 활동의 구심점이 될 수 있다는 교훈을 얻을 수 있다.

둘째, 이러한 배경 하에 전담 팀올 발족하여 구체적인 프로그램들을 진행하며 전문능력을 키워야 할 것이다. 특히 프로그램들이 다양하게 진화·진형되면 관련단체와의 유기적인 협력 활동이 필수적임을 배울 수 있다. 이럴수록 전담 팀의 전문능력이 중요해질 것이다. 유한킴 벌리의 경우 이러한 전담 팀의 전문능력이 구현된 모습을 곳곳에서 발견할 수 있었으며, 한 예로 활동대상별로 공익에 대한 참여 프로그램을 매뉴얼화 하여 운영하고 있는 것을 들 수 있다(표 4 참조). 특히 기업이 사회공헌활동을 하는 이유와 동기를 소비자들이 공감할 수 있도록 구체화하는 것이 $\mathrm{CRM}$ 의 효과를 높이는데 중요하다는 점과 CRM활동은 유사한 경쟁 브 랬드 간에 브랜드차별화 전략으로서 활용 가치가 있다는 점을 시사하고 있는 Baron 둥 (Baron et al., 2000)의 연구를 고려할 때 전담 팀의 전문능력과 구체적인 실행능력은 더욱 
더 중요합을 인식하여야 할 것 같다.

셋째, 유한킴벌리의 공헌활동이 오래된 것은 사실이지만, <그립 2>에서 볼 수 있둣이 숲 운동의 급속한 발전과정과 이에 대한 적극적 참여는 최근 4 5년간에 이루어졌다. 즉, 공익 연계마케팅활동이 어렵게 보이는 것은 사실이지만, 본 사례연구의 결과는 공익연계마케팅 활동도 그 모멘텀만 확보되면 딸리 발전할 수 있다는 가능성을 시사하고 있다.

넷쩨, 규모가 큰 대기업의 경우는 공읙연계마케팅활동을 마케팅할동 대안의 하나로서 접 근할 수 있겠지만, 규모가 그리 크지 않은 기업에서는 마케팅의 효과성과 효율성을 고려할 때 제품 브랜드 중심의 마케팅 기의 기업이미지 중심의 마케팀, 즉, 마케팅활동의 대상 수준 에 관한 의사결정이 필요할 것이다. 즉 유한킴벌리의 경우처럽 규모가 그리 크지 않은 기업 에서는 공익연계마케팅활동을 기업 차원과 연결한 후 이 효과가 브랜드와 제품 수준으로 이 월되는 후광효과(halo effect)를 고려하며 그 활동을 진행하는 것이 바람직할 것이다. 즉 유한킴벌리의 경우 공익활동과 기업, 그리고 브랜드 간의 연관성이 소비자의 기억 속에 높 게 자리잡아 그 효과를 발휘하고 있는 점은 기존의 많은 연구 결과들이 이미 제시하고 있는 부분이다(Brian \& Nowak, 2000; Brown \& Dacin, 1997; Drumwright, 1996; Pringle \& Mar jorie, 1999; Varadarajan \& Menon, 1988).

<표 4> 유한킴벌리의 대상별 공익프로그램 커뮤니케이션 매뉴얼 컨셉트"

\begin{tabular}{|c|c|}
\hline 대 상 & 할용요소와 도구 \\
\hline 임직원 & $\begin{array}{l}\text { 기업이념과 윤리강령에 반영 ; 신입사원 교육 ; 사보 소개 ; 전자메일로 } \\
\text { 참여방법 소개 ; 기획 행사 및 조직별 활동 소개와 시상 }\end{array}$ \\
\hline 정부 & 수상(훈장, 표창, 공적조서 자료)； 공동 프로그램 \\
\hline 언론 & 사례 소개 ; 공동 프로그램 ; 공익 광고 ; 프로그램 참여 \\
\hline 공중 & $\begin{array}{l}\text { 공익 광고 ; 참여 행사, 책자, 연구활동 및 연구서 보급 ; 일관되고 긍정 } \\
\text { 적인 형상을 제공하는 공익 프로그램 창출 및 실시 }\end{array}$ \\
\hline $\mathrm{NGO}$ & 협력할동； 자료공유； 후원； 공동행사 \\
\hline 금압, 지역사혀, 경쟁사 & \\
\hline
\end{tabular}

* 자료원 : 유한킴벌리 경영사례 발표자료(2003. 8.)

마지막으로 본 연구는 한 기업의 사례 연구임에 따라 공익연계마케팅할동에 대해 더 생각 해 봐야 할 과제들도 수반하고 있다. 먼저 협력활동 둥 다양한 공익연계할동을 수행함에 있 어 내부 임직원에게 엄청난 에너지, 시간 등 자원을 요구하게 될 것이다. 특히 이러한 요구 는 협력활동을 수행할수록 더 큰 부담이 될 것이다. 이률 어떠한 조직적 메커니즘으로 관리 할 수 있을 것인가는 해결하여야 할 큰 숙제가 둴 것이다. 이와 관련해서 전담부서는 이러 한 요구 사항들올 어떻게 정리하여 내부마케팅을 하여야 할 지를, 그리고 이러한 일련의 업 무를 어떻게 시스템화 해 나가야 할 것인지를 고민하여야 할 것이다. 유한킴벌리의 경우 사 회공헌활동 관련 내부조직은 대외협력실과 커뮤니케이션부로 이 두 부서가 주체가 되어 관 련활동올 비교적 효율적으로 운영하고 있는 것으로 평가되지만 이러한 조직 관련 사항은 항 상 개선의 여지를 안고 있을 것이다.

또 걱정하여야 할 과제는 공익연계활동이 다양해짐에 따라 다양한 활동간의 우선 순위률 어떻게 조정하여야 할 것인 지에 관한 것이다. 예률 들어 유한킴벌리의 경우에도 환경교육, 연구·출판 지원, 그리고 협력활동 간의 우선 순위를 어뗳게 결정하고 유지해 나갈 것인가를 계속 고민할 것이다. 다시 말하면 너무 많은 활동들이 연루되면 공익연계마케텅활동의 효과 
가 희석되지 않을 지에 대하여 고민하여야 할 것이다.

이와 더불어 사회공헌활동에 대한 보다 최근의 높은 관심(예 : 삼성의 나눔경영)으로 인 하여 제시되고 있는 성과, 즉, 태도와 효과에 관한 다양한 측정치(Mignan, 2001; 한은경·류 은아, 2003)를 고려할 때, 활동의 우선 순위와 이에 따른 적절한 효과 측정치의 개발과 활 용은 관심 있는 기업에게 중요한 과제가 될 것이다.

어찌 되었든 유한킴벌리의 장기적이며 다양하고 구체적인 공익연계마케팅활동과 프로그램 들은 우리나라의 다른 기업이 적극 벤치마킹하여 활용해볼 만한 가치가 매우 높은 사례이다. 


\section{<참고문헌>}

유한킴벌리 경영사례 발표자료, 2003. 8.

윤각-서상희(2003), "기업의 사회공헌활동과 기업광고가 기업이미지와 브랜드태도 형성에 미치는 영향력에 관한 연구," 광고연구, 제61호, 47-72.

조형오(2000), "공익연계 광고메시지가 소비자의 의사결정 과정에 미치는 영향," 광고연

구, 제49호, 231-249.

한은경 · 류은아(2003), "기업의 사희책임활동이 구매의도에 미치는 영향에 관한 연구,"

광고연구, 제60호, 155-177.

Aaker, David A. (1991), Managing Brand Equity, New York: Free Press.

Arnot t, N. (1994), "Marketing With a Passion," Sales and Marketing Management, 146

(January), 64-71.

Baron, M. J., A. D. Miyazaki, \& K. A. Taylor (2000), "The Inf luence of Cause-Related Marketing on Consumer Choice: Does One Good Turn Deserve Another?" Journal of the Academy of Marketing Science, 28 (2), 248-262.

Brian, D. T. \& L. I. Nowak (2000), "Toward Effective Use of Cause-Related Marketing Alliances," Journal of Product \& Brand Management, 9 (7), 474-484.

Brown, T. J. \& P. A. Dacin (1997), "The Company and the Product: Corporate Associations and Consumer Product Responses," Journal of Marketing, 61 (January), 68-84.

Carringer, P. T. (1994), "Not Just a Worthy Cause: Cause-Related Marketing Delivers the Goods and the Good," American Advertising, 10 (Spring), 16-19.

Drumwright, M. E. (1996), "Company Advertising With a Social Dimension: The Role of Noneconomic Criteria," Journal of Marketing, 60 (October), 71-87.

Garfield, B. (1993), "This Heavy-Handed Ad Exploits Someone New," Advertising Age, 64 (May, 10), 50 .

Gutman, Jonathan (1982), "A Means-End Chain Model Based on Consumer Categorization Processes," Journal of Marketing, Vol. 46 (Spring), 60-72.

Keller, Kevin Lane (1993), “Conceptualizing, Measuring, and Managing Customer-Based Brand Equity," Journal of Marketing, Vol. 57 (January), 1-22.

Kotler, Philip (1997), Marketing Management: Analysis, Planning, Implementation, and Control, Prent ice Hall, Englewood Cliffs, N.J.

Krol 1, C. (1996), "Consumers Note Marketers' Good Causes: Roper," Advert ising Age, 11 (November), 51.

Mignan, I. (2001), “Consumers' Perceptions of Corporate Social Responsibility: A Cross-Cultural Comparison," Journal of Business Ethics, 30 (1) , 57-72.

Miller, C. (1992), "Advertiser Promote Racial Harmony: Nike Criticized," Marketing News, 26 (July, 6), 1-10.

Murphy, I. P. (1997), "Pillsbury Proves Charity, Marketing Begins at Home," Marketing News, 31 (February, 17), 16.

Pringle, H. \& T. Marjorie (1999), Brand Spirit - How Cause-Related Marketing Builds 
Brands, NY: John Wiley \& Sons.

Ross \& Patterson (1991), "Consumer Perceptions of Organization That Use of CauseRelated Market ing," Journal of the Academy of Marketing Science, 20 (1), 93-97.

Rust, Roland T., Valarie A. Zeithaml and Katherine N. Lemon (2000), Driving Customer Equity, The Free Press.

Sen, S, \& V. G. Morwitz (1996), "Consumer Reactions to a Provider's Position on Social Issues: The Effect of Varying Frames of Reference," Journal of Consumer Psychology, 5 (1), 27-48.

Smith, G. \& R. Stodgehill III (1994), "Are Good Causes Good Marketing?" Business Heek, 21 (March), 64-66.

Varadarajan, P. Rajan \& Anil Menon (1988), "Cause-Related Marketing: A Coalignment of Marketing Strategy and Corporate Philanthropy," Journal of Marketing, Vol. 52 (July), 58-74.

Hebb, D. J. \& L. A. Mohr (1998), “A Typology of Consumer Responses to Cause-Related Marketing: From Skeptics to Socially Concerned," Journal of Public Policy \& Marketing, 17 (Fal1), 226-238.

www. forestkorea org

www.yuhan-kimberly.co.kr 